Journal of Southeast Asian

\title{
Two Poems: Your American Songbook \& Context Clues
}

Sokunthary Svay

sok.svay@gmail.com

Follow this and additional works at: https://docs.lib.purdue.edu/jsaaea

Part of the Bilingual, Multilingual, and Multicultural Education Commons

\section{Recommended Citation}

Svay, Sokunthary (2021) "Two Poems: Your American Songbook \& Context Clues," Journal of Southeast Asian American Education and Advancement. Vol. 16 : Iss. 1, Article 4.

DOI: $10.7771 / 2153-8999.1236$

Available at: https://docs.lib.purdue.edu/jsaaea/vol16/iss1/4

This document has been made available through Purdue e-Pubs, a service of the Purdue University Libraries. Please contact epubs@purdue.edu for additional information.

This is an Open Access journal. This means that it uses a funding model that does not charge readers or their institutions for access. Readers may freely read, download, copy, distribute, print, search, or link to the full texts of articles. This journal is covered under the CC BY-NC-ND license. 


\section{ISAAEA Journal of Southeast Asian American Education and Advancement}

Vol. 16 Iss. 1 (2021)

WWW.JSAAEA.org

\section{Creative and Literary Works}

Two Poems

\section{Sokunthary Svay}

\section{Your American Songbook}

Ameling, Caballé, Norman, Bonney, Fleming, Battle

Arpeggios, immunizations

Successful completion for the fall, English Major code

Passport expired 04 Nov 2012

Eyebrows thin as commas hair articulates the plump

Drug-free face. A runny signature.

Naturalization certificate a partially sleepy-eyed citizen one less

boyfriend two sizes down.

I don't want to know the stars in Ashbery's "America” they feel of asterisks beside the names of my family on the refugee pages indications of sickness, by-theways

Who is "your janitor"? My janitor is a father who gave me his name, books with titles left for garbage pick up by NYU.

\footnotetext{
(c)

SDRERIIGHISRESERNEDR Readers are free to copy, display, and distribute this article, as long as the work is attributed to the author(s) and the Journal of Southeast Asian American Education \& Advancement, it is distributed for non-commercial purposes only, and no alteration or transformation is made in the work. More details of this Creative Commons license are available at http://creativecommons.org/licenses/by-nc-nd/3.0/. All other uses must be approved by the author(s) or JSAAEA. Journal of Southeast Asian American Education \& Advancement, Vol. 16. Iss. 1. (2021) ISSN: 2153-8999
} 
Honors and Awards skills education transcriber, flute, cum laude MS office

I run into Kimiko at the bar after she teaches. She rips pages out of a discarded book and we do a writing exercise over martinis. Highlight words from a self-help book. I found her found words.

Aggressively dissatisfied but

A surprising body, which is

A plant in some way

Groups children

From homes happy and happy

Excepting for the unhappy

Blood.

John keeps mentioning this janitor and this country. I sang an Aaron Copland song for an audition:

“Long Time Ago" Ballad of lost love where "droop'd the willow" and "back

the billow

Ashbery’s “Terrain / Glistening” as "her blue eyes glisten'd”

American songs are in the eyes

in what we see. Or in the luring across the waters to Europe

in the languages and songs, o quand je dors

morgen

Mozartian sixteenths staccato of the immigrant at the conveyor belt my brother assembles pistons. Pistons. 
That hymn we sang in the church for the god I don't believe in exalts

"How can I keep from singing?"

\section{Context Clues}

Nyam

Nyum

Nyim

Nom

Nawm

Nov

Ngai

Nung

No

Not

Nut

Near

$\mathrm{Nub}$

Nun

Now

Naught

Nope

Next

Nip

Knot

These are the sounds and yet the words differ. I want to say "ut ey dtay" but that won't put you at ease, no more than "don't worry" does in English. The sounds float in my memory and release in situations where the sounds become relevant. Unearthed for those who pronounce the labiodental, lip-to-tongue sounds with a cluck, a glottal, a breath, aspirate, an aspiration. Here. How. Hold. Home. Help. Who? Humble. Heart. Whole.
Wear
Knear
Thear
Twear
Trey
Ey
Bey
Srey
Parey
Tmey
Sdey 


\section{Soursdey}

What is translation? What do their English equivalents matter? They aspire for accuracy, but are not answers. Diphthongs and umlauts, vowels extending into different shapes of the mouth, closed or opened in the back, swallowed and regurgitated.

Bei

Bong

Baht

Borey

Bai

Badt

Baich

Butt

Bar

Boss

Bold

Bit

Bye

Buy

Bend

Twist the diction until it sounds authentic, local, regional, mistaken-for someone else. Speak to belong, speak to other, to own-whether one's or another's. Crippling crunch of consonants. Crew of long vowels crashing into the sea. This is history.

For a language with vocal stops, child and mother end with open vowels as if moaning, calling: oan, mae

My Mae is my cry. Before I have the words in the womb, in the crib, the cry elongates because duration is the key to being heard. I endure.

Even "Mak" with its vocal stops, I defy it, shout Maaaa-(k). Hold the "a" into an "ah." Does this relieve, does it sing? My voices teacher wants me to sing pure vowels in Italian opera. What is purity? What makes a language impure?

A woman answers yes with a "dja" (unaspirated) the "a" lengthened while men are cut off in "baht" the tongue stopping itself behind the upper teeth. The teeth a cage of mouth that seeks opening. What gender opens and what pricks.

I seek trust in the seed of this language // BUN DTAY (but) // it grows with uncertainty. 


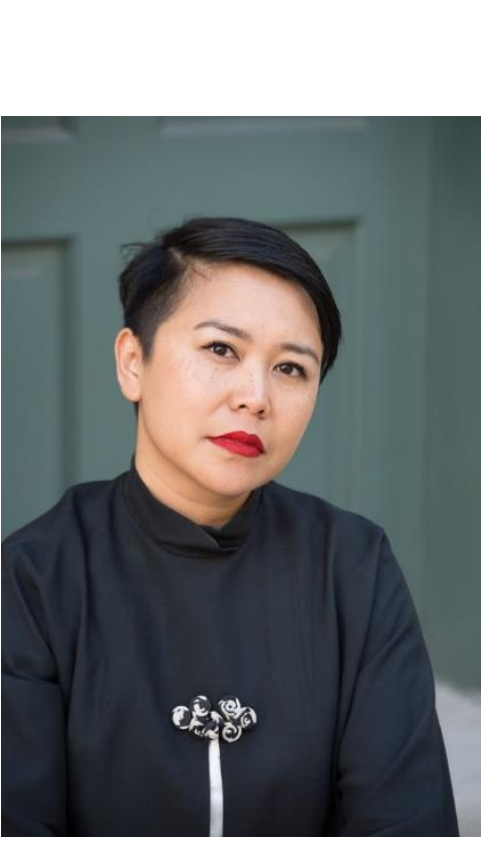

\begin{abstract}
About the Author
Sokunthary Svay is a Khmer writer from New York City. A founding member of the Cambodian American Literary Arts Association (CALAA). She has received fellowships from the American Opera Project, Poets House, Willow Books, and CUNY, as well as commissions from Washington National Opera, the Asian American Writers' Workshop, and ISSUE Project Room. In addition to publishing a poetry collection, Apsara in New York (Willow Books, 2017), Svay has had her writing anthologized and performed by actors and singers. Svay's first opera, Woman of Letters, set by composer Liliya Ugay, received its world premiere at the Kennedy Center in January 2020 as part of the American Opera Initiative. The recent recipient of the OPERA America IDEA Grant, she is currently working on a new opera called Chhlong Tonle. She teaches English at Queens College (CUNY).
\end{abstract}




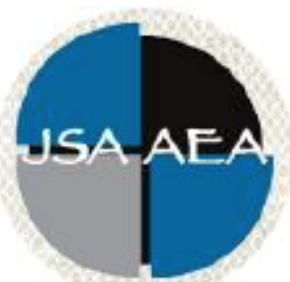

Vol.16 Iss.1 (2021)

\section{Journal of Southeast Asian American Education and Advancement}

\author{
Editor \\ Dr. Wayne E. Wright \\ Purdue University \\ Associate Editors \\ Dr. Chhany Sak-Humphry \\ University of Hawaii at Manoa \\ Dr. Phitsamay Sychitkokhong Uy \\ University of Massachusetts, Lowell \\ Book Review Editor \\ Dr. Vichet Chhuon \\ University of Minnesota \\ Creative Works Editor \\ Bryan Thao Worra \\ Lao Assistance Center \\ Journal Manager \\ Chen Li \\ Jeffrey Wright \\ Purdue University
}

Editorial Review Board

Dr. Steve Arounsack

California State University, Stanislaus

Dr. Sovicheth Boun

Salem State University

Dr. Virak Chan

Purdue University

Dr. Loan Dao

University of Massachusetts Boston
Dr. Carl L. Bankston III

Tulane University

Dr. Phala Chea

Lowell Public Schools

Dr. George Chigas

University of Massachusetts, Lowell

Dr. Hien Duc Do

San Jose State University 


\author{
Dr. Linh Dang \\ KIPP DC Headquarters \\ Dr. Sophal Ear \\ Occidental College \\ Dr. Vincent K. Her \\ University of Wisconsin, Eau Claire \\ Dr. Nancy H. Hornberger \\ University of Pennsylvania \\ Dr. Peter Tan Keo \\ New York University \\ Dr. Yvonne Kwan \\ San Jose State University \\ Dr. Ravy Lao \\ California State University, Los Angeles \\ Dr. Stacey Lee \\ University of Wisconsin, Madison \\ Dr. Jacqueline Mac \\ Northern Illinois University \\ Dr. Bic Ngo \\ University of Minnesota \\ Dr. Leakhena Nou \\ California State University, Long Beach \\ Dr. Mark Pfeifer \\ SUNY Institute of Technology \\ Dr. Loan T. Phan \\ University of New Hampshire \\ Dr. Karen Quintiliani \\ California State University, Long Beach \\ Dr. Angela Reyes \\ Hunter College \\ The City University of New York \\ Dr. Fay Shin \\ California State University, Long Beach \\ Dr. Christine Su \\ College of San Mateo \\ Dr. Alisia Tran \\ Arizona State University \\ Dr. Khatharya Um \\ University of California, Berkeley \\ Dr. Kim Tran \\ University of California, Los Angeles, \\ Glendale Community College \\ Dr. Molly Wiebe \\ The University of Texas at Austin \\ Dr. Changming Duan \\ University of Missouri-Kansas City \\ Dr. Sothy Eng \\ Lehigh University \\ Dr. Jeremy Hein \\ University of Wisconsin, Eau Claire \\ Dr. Peter Nien-Chu Kiang \\ University of Massachusetts, Boston \\ Dr. Kevin K. Kumashiro \\ University of Illinois, Chicago \\ Dr. Ha Lam \\ Independent Scholar \\ Dr. Jonathan H. X. Lee \\ San Francisco State University \\ Dr. Monirith Ly \\ Royal University of Phnom Penh \\ Dr. Sue Needham \\ California State University, Dominguez Hills \\ Dr. Max Niedzwiecki \\ Daylight Consulting Group \\ Dr. Clara Park \\ California State University, Northridge \\ Dr. Giang Pham \\ University of Massachusetts Amherst \\ Dr. Malaphone Phommasa \\ University of California Santa Barbara \\ Dr. Kalyani Rai \\ University of Wisconsin-Milwaukee \\ Dr. Cathy J. Schlund-Vials \\ University of Connecticut, Storrs \\ Dr. Nancy J. Smith-Hefner \\ Boston University \\ Dr. Yer J. Thao \\ Portland State University \\ Dr. Monica M. Trieu \\ Purdue University \\ Dr. Silvy Un \\ Saint Paul Public Schools \\ Dr. Linda Trinh Vo \\ University of California, Irvine \\ Dr. Varaxy Yi Borromeo \\ California State University, Fresno \\ Dr. Yang Sao Xiong \\ The University of Wisconsin-Madison

\section{Dr. Zha Blong Xiong} \\ University of Minnesota
}




\section{Doctoral Student Editorial Review Board}

Diana Chandara
University of Minnesota-Twin Cities
Bao Diep
University of Minnesota-Twin Cities
Vanessa Sovanika Na
University of California San Diego
Khoi Nguyen
George Mason University
Hoa Nha Nguyen
Boston College
Linda Marie Pheng
University of Wisconsin-Madison
Latana Thaviseth
University of California Los Angeles
Melissa Vang
San Diego State University

Diana Chandara

Bao Diep

rsity of Minnesota-Twin Cities

of California San Diego

rge Mason University

Hoa Nha Nguyen

Boston College

rsity of Wisconsin-Madison

ity of California Los Angeles

San Diego State University

\author{
Kassandra Chhay \\ University of Minnesota-Twin Cities \\ Annie BichLoan Duong \\ San Joaquin County Office of Education \\ Nielson Hul \\ Cornell University \\ Dung Minh Mao \\ University of Minnesota-Twin Cities \\ Thien-Huong Ninh \\ University of Southern California \\ Krissyvan Truong \\ Claremont Graduate University \\ Mai Vang \\ University of Massachusetts Boston \\ Thong Vang \\ University of Minnesota-Twin Cities
}

Soua Xiong

San Diego State University

Claremont Graduate University 